\title{
Transforming the Alliance: The Bush Administration's Vision of NATO
}

\author{
by Edward Rhodes*
}

For political scientists and for policymakers on both sides of the Atlantic, the end of the Cold War raised profound questions about the future of the North Atlantic Alliance - whether it would continue to exist, whether it would continue to play a significant role, and, if it survived and continued to play a significant role, what that role would be and what capabilities would be needed to perform it. Since June 2001, the administration of President George W. Bush has weighed in on these questions. What has emerged has been an extraordinarily coherent if not entirely unproblematic set of propositions about the nature of NATO, the role it needs to play in the world, and how the Alliance and its capabilities will have to evolve.

The new American vision of NATO, as explained in a steady flow of statements, speeches, and documents released by top administration figures, including the President himself, is remarkable not only for the way it diagnoses the present situation but for the way it reinterprets the history of U.S.-European relations and for the vision it offers of the road ahead for the free world. To comprehend fully the Bush Administration's conception of NATO, it is thus important to look at what the administration has to say about the past and the future, as well as at what it is saying about current U.S. policy preferences.

This examination of the Bush Administration's vision of NATO - past, present, and future - is a useful exercise for a number of reasons. For the Bush Administration, as for its predecessors, NATO is very much the cornerstone of U.S.-European relations. Understanding how it conceives of NATO is thus critical to understanding its thinking about why and how Western democracies can and must work together. Equally important, it reveals the administration's thinking about the existential and immediate challenges Western societies face. An examination of the administration's views regarding NATO is, in other words, an ideal window for examining the administration's larger conception of how a liberal, democratic world order is to be built.

\section{From Warsaw to Prague}

In June 2001, with the November 2002 NATO Summit in Prague already on the horizon, President Bush traveled to Europe. For a number of important symbolic reasons, the President chose Warsaw as the location for a major policy address on the future of NATO. In Warsaw he explained his administration's

\footnotetext{
* Edward Rhodes is the director of the Center for Global Security and Democracy at Rutgers University, New Brunswick, New Jersey.
} 
views on the critical questions of NATO enlargement, NATO's role in the Balkans, and NATO's engagement with Russia, and implicitly set out the administration's agenda for the Prague Summit. In both symbolic and practical terms, the Warsaw speech was neatly framed: two days before, the President was in Brussels addressing NATO, and the day after he flew to Ljubljana, Slovenia to meet with Russian President Vladimir Putin for the first time.

In the seventeen months between Warsaw and Prague, the administration developed and refined its thinking and its message, but, despite the traumatic events of 11 September 2001, it never departed in any significant way from the conception of a transformed Atlantic Alliance that was enunciated in Warsaw. The first meeting of the NATO-Russia Council in May 2002 and, more importantly, the Prague Summit - which resulted in invitations to seven Eastern European nations to join NATO - were important steps forward in operationalizing America's new vision of the Atlantic relationship.

As the U.S. Ambassador to NATO explained on the eve of the Prague Summit, "our view is at once simple and yet far-reaching: we want the Prague Summit to launch a whole-scale transformation of the NATO Alliance for the twenty-first century. The old NATO served us well, but our task now is to build a transformed Alliance that can extend the peace and our common security for the next generation of Europeans and Americans."1 This transformation involved the three new priorities enunciated by the Bush administration - new members, new relationships, and new capabilities - and a broadening of NATO's agenda from continental concerns to global ones.

\section{Continuity and Change}

Perhaps the single most important thing to realize about the Bush Administration's understanding of NATO is that, in its view, the struggle in which NATO is engaged is not one between social or economic systems, or between ways of life, or between civilizations. In the final analysis, it is not a competition between capitalism and socialism, or between liberalism and communism, or between West and East. At times, of course, it may take any of these forms. Ultimately, however, it is a struggle between good and evil. This, according to the current administration's view, is a struggle that has spanned the ages. The particular form or identity the adversary takes may change - that is, evil has many faces - but the fundamental opposition of good and evil, of freedom on the one hand and tyranny and oppression on the other, is unchanging.

This is the first great perceived continuity that shapes the thinking of the Bush Administration. The second is America itself, and its relationship with Europe. Three important elements of putative American constancy in its transat-

\footnotetext{
${ }^{1}$ R. Nicholas Burns, "Launching NATO's Transformation at Prague," Manfred Woerner Memorial Lecture, Konrad Adenauer Stiftung, Berlin, Germany, 30 October 2002, 1. Full text can be accessed at: http://www.kas.de/publikationen/2002/999 dokument.html
} 
lantic dealings can be identified. The implication in each case is that constancy in the past implies constancy in the present and constancy in the future.

First, in the Bush Administration's account of history, America's faith in a free Europe never wavered. While the United States may have acquiesced in certain evils - it may have stood aside when the Western powers appeased Hitler at Munich, and it may have participated in the division of Europe at Yalta - in its heart it always knew these steps were wrong and would not stand. In the end, of course, this faith triumphed, as faith inevitably does. Speaking in Vilnius, for example, the President said, "Many doubted that freedom would come to this country, but the United States always recognized an independent Lithuania. We knew that this continent would not remain divided. We knew that arbitrary lines drawn by dictators would be erased, and those lines are now gone."2

Second, in the administration's telling, America's commitment to the Atlantic partnership, a partnership based on this common faith, never weakened and was never called into doubt - and by implication can never weaken or be doubted in the future. Neither dangers nor petty arguments have threatened or will ever threaten it. "These trans-Atlantic ties," the President proudly claimed at Warsaw, "could not be severed by U-boats. They could not be cut by checkpoints and barbed wire. They were not ended by SS-20s and nuclear blackmail. And they certainly will not be broken by commercial quarrels and political debates." 3

Speaking three hours earlier, National Security Advisor Condoleezza Rice underscored this extraordinary American constancy and the logical conclusion to be drawn from it, explaining that "the point that he [the President] has been making is that Europe is changing, Europe has been changing, it's changing for the better - but the one thing that will not change is the American commitment to Europe, the American commitment to partnership with Europe, and the American commitment to the fact that that partnership gives us an opportunity to do many extraordinary things in the world."

NATO is both the seal and the keystone of this permanent U.S. commitment to the Atlantic relationship. "There is," Under-Secretary of State Marc Grossman explained, "no greater example of the strong and enduring ties between Europe and America than the NATO Alliance. For more than half a century it has been the indispensable link between our peoples, ensuring our common security and uniting us in pursuit of a free and democratic future." ${ }^{5}$

Although the administration has typically explained the unbreakable

\footnotetext{
${ }^{2}$ George W. Bush, "Remarks," Vilnius, 23 November 2002, 1.

${ }^{3}$ George W. Bush, "Remarks,” Warsaw University, 15 June 2001, 2.

${ }^{4}$ Condoleezza Rice, "Press Briefing by National Security Advisor Condoleezza Rice," Warsaw Marriott Hotel, Warsaw, Poland, 15 June 15, 1.

${ }^{5}$ Marc Grossman, "NATO Enlargement: Remarks to the Chicago Council on Foreign Relations," Chicago, 11 September 2002, 2.
} 
nature of this Atlantic partnership by referring to common values, occasionally it has accounted for it in the more pragmatic terms of realpolitik, particularly since September 11. U.S. Ambassador to NATO Nicholas Burns, for example, explained it to his NATO colleagues this way: "With Europe's contributions in mind, we Americans remember something else today: that despite our awesome power, we cannot go it alone in the world. America needs our friends and, especially, our NATO Allies. Neither isolationism nor unilateralism can ever be America's course."

Third, in the Bush Administration's construction of history, America's relationship with the nations of Eastern Europe has always been one of friendship. In this view, the correct understanding of the Cold War is not that NATO nations and Warsaw Pact nations were pitted against each other in a potentially deadly geopolitical rivalry or competition between socio-economic systems, but that NATO and Pact nations were brothers in a struggle against evil, a struggle in which the Pact nations in fact bore the heaviest burden. Given this history, the nations of Eastern Europe are to be honored rather than regarded with suspicion. As President Bush proclaimed, "These heroic nations have survived tyranny, they have won their liberty and earned their place among free nations. America has always considered them friends, and we will always be proud to call them allies."6 The fact that Eastern European military facilities and, presumably, cities had for decades been included in American nuclear targeting options, and that Eastern European troops and American troops might well have come into combat against each other, has been excised from this version of history.

Given this construction of history - this claim for America's firm, faithful, brotherly stand on the side of freedom, and in opposition to whatever face evil presented - the American understanding of the future - that is, that America can be relied upon with certainty to protect others in the community of freedom when they are threatened - follows logically. As President Bush reassured Romania upon their accession to NATO membership, "The promises of our Alliance are sacred, and we will keep our pledges to all the nations that join us. ... As a NATO ally, you can have this confidence - no one will be able to take away the freedom of your country." 7

\section{Transforming the Alliance}

While the administration's vision of NATO is thus built on what it regards as two great continuities - continuity in the underlying, essential nature of the

\footnotetext{
${ }^{6}$ George W. Bush, "President Bush Meets with Central European Foreign Ministers: Remarks by the President with Central European Foreign Ministers," the White House, Washington, D.C., 8 May 2003, 1.

${ }^{7}$ George W. Bush, "President Bush Welcomes Romania to NATO: Remarks by the President to the Citizens of Romania," Bucharest, Romania, 23 November 2002, 1.
} 
adversary (evil itself) and in America's commitment to oppose it - at the same time the administration understands its policies as representing fundamental change. As Secretary of State Powell has candidly observed, the enlargement of NATO is conceived as "part of an ambitious agenda whose goal is to transform the Alliance." 8

Part of this transformation reflects the changed face of evil, from Soviet Communism to tyranny and terror. We will discuss the implications of this below. More fundamentally, however, it reflects the administration's belief that the time has come for a basic change in strategy. According to this view, mankind's struggle against evil has entered a new phase.

There are several key elements in the administration's analysis. First, evil's ultimate defeat is certain. Second, however, evil has not yet been vanquished. We have not reached "the end of history." America and NATO must not let down their guard, but must gird themselves for renewed battle. Third, even while continuing the struggle, we must acknowledge that an important victory has been won, and celebrate this fact. (Thus it is logically possible for the President to assert in the same speech both that "the long night of fear, uncertainty, and loneliness is over" and that "our alliance of freedom is being tested again by new and terrible dangers." ${ }^{\circ}$ )

Fourth, the gains that have been won in that victory are irreversible. There will be no more setbacks in Europe, like those of Munich and Yalta. One of the things the President means when he says "No more Munichs" and "No more Yaltas" is that "we will not trade away the fate of free European peoples." 10 The promise associated with NATO membership is that "from now on, what you build, you keep. No one can take away your freedom or your country." 11

Fifth, this victory represented a watershed (not an end, but nonetheless the beginning of the end) in human history and in the struggle of free peoples to preserve for themselves, and to regain for all of humanity, their birthright of freedom. As Secretary of State Powell explained to the Senate in making the case for NATO enlargement, "the West's victory in the Cold War and the defeat of Soviet communism signaled a decisive turning point in modern history - a victory for freedom and democracy." 12

If we are to understand the administration's attitude and policies toward NATO, it is necessary to take seriously this description of the winning of the Cold War as a "turning point" in humanity's struggle for freedom. On the one hand, the struggle continues, and the Alliance remains central to dealing

\footnotetext{
${ }^{8}$ Colin L. Powell, “An Enlarged NATO: Mending Fences and Moving Forward on Iraq," Testimony before the Senate Foreign Relations Committee, Washington, D.C., 29 April 2003, 2.

${ }^{9}$ George W. Bush, "Remarks," Vilnius, 1.

${ }^{10}$ George W. Bush, "Remarks," Warsaw University, 2.

${ }^{11}$ Ibid., 2.

${ }^{12}$ Colin L. Powell, “An Enlarged NATO,” 2.
} 
with challenges ranging from ethnic cleansing to international terrorism. On the other hand, the current world situation presents an "historic opportunity," as the President observed in his National Security Strategy. ${ }^{13}$ Thanks to victories over fascism, militarism, and communism, we now have the best opportunity since the rise of the nation-state in the seventeenth century to harness the power of the world's great nations to pull together toward peace, rather than to work in opposition to each other. ${ }^{14}$ "We will work to translate this moment of influence into decades of peace, prosperity, and liberty. ... The aim of this strategy is to help make the world not just safer but better." ${ }^{15}$ This moment, though, calls for a new strategy.

Americans are inclined to think of war as having two phases: an initial, defensive phase in which defeat is averted and core values are preserved, and then a second phase in which the enemy is rolled back and victory is ultimately achieved. At the juncture between these two phases lies the turning point. This is where we now stand.

In the administration's reading of history, the Cold War lies in the defensive phase: "As the Iron Curtain fell across Europe, and walls and barbed wire were raised, the free nations of Europe and the United States gathered their will and courage and formed the greatest alliance of liberty. Through forty winters of Cold War, NATO defended the security of the Western world, and held in trust the idea of freedom for all the peoples of Europe." 16 This phase ended when "the peoples of Central and Eastern Europe took history into their own hands and took back their rights and freedom." ${ }^{17}$ Or, as the President explained when he visited NATO headquarters in Belgium on his way to Warsaw in 2001, "Our nations established NATO to provide security for the free peoples of Europe and North America; to build a grand alliance of freedom to defend values which were won at great cost. We've succeeded, in part. The NATO Alliance deterred the Soviet Union. It provided the time and space for free peoples to defeat communism. ... Now we have a great opportunity to build a Europe whole, free and at peace, with this grand alliance of liberty at its very core. That work has begun."18

Even at that early date, before Warsaw and before Prague, the President made clear that the work that was now begun involved not the defense

\footnotetext{
${ }^{13}$ George W. Bush, "The National Security Strategy of the United States of America," 17 September 2002, 1.

${ }^{14}$ As President Bush outlined these past threats in the National Security Strategy, "the militant visions of class, nation, and race which promised utopia and delivered misery have been defeated and discredited." Ibid., 2; ibid., 1.

${ }^{15}$ Ibid., 2.

${ }^{16}$ George W. Bush, "Remarks by the President with Central European Foreign Ministers," Washington, D.C., 1.

${ }^{17}$ Ibid.

${ }^{18}$ George W. Bush, "Remarks by the President at Opening of NATO Meeting," NATO Headquarters, Brussels, Belgium, 13 June 2001, 1. Emphasis added.
} 
of freedom but its extension. It involved acknowledging Central and Eastern Europe's great victory and guaranteeing the permanence of freedom's sway through the admission of new members to NATO. It involved reaching out to other freedom-loving peoples through new partnerships. And it involved confronting evil in its new forms by stopping terrorism and overthrowing tyranny in the Balkans.

\section{An Enlarged House}

The first new agenda item that the United States has insisted must be part of NATO's transformation has thus been admission of new members to the Alliance. It is easy from a post-Prague or even post-Warsaw perspective to forget that prior to 2001 the notion of a "large" second round of NATO enlargement was dismissed in most American circles, as in most European ones, as both implausible and misguided. Enlargement, if it took place, would probably, it was presumed, be limited to a smoothing out of NATO's logical geo-military borders - possibly simply adding Slovenia and Slovakia to the Alliance to eliminate the geographic anomaly of Hungarian membership and to solidify NATO's Balkan front. Admission of the Baltic states was generally regarded as geo-political folly; it would needlessly provoke Russian hostility and - since, if the Baltic states were ever attacked in force, they would be nearly impossible to defend with conventional means - lower the nuclear threshold in Europe. Enlargement to include Romania and Bulgaria was typically seen as a net military loss, as the ability of these states to contribute militarily to the defense of the Alliance would be more than offset by the cost of modernizing their forces to NATO standards and by the potential disputes into which they could conceivably drag it.

As Deputy National Security Advisor Stephen Hadley explained six weeks before Prague, "in the first round of enlargement we were still stuck in the Cold War logic that assume[d] that more members meant a greater burden rather than a greater benefit. That by expanding the perimeter of NATO's defensive line we were adding to our problems."19

Part of the shift in American attitude between the first and second rounds of enlargement, of course, reflected a changed evaluation of the security threat, from a concern about large-scale, cross-border invasions to worries about Balkan dictators and Islamic terrorists. As Hadley continued, "Today we are moving beyond this old-think. If, for example, Romania enters the Alliance, we will spend little time worrying about defending Romania against a hypothetical Soviet threat. We will spend time finding the best possible use for Romania's capabilities, such as its battalion-strength combat unit, the Red Scorpions, that is already serving in Afghanistan." 20

\footnotetext{
${ }^{19}$ Stephen Hadley, "Challenges and Change for NATO," 3. NATO text can be found at: http://www.nato.int/docu/speech/2002/s021003e.htm

${ }^{20}$ Ibid.
} 
Without any disrespect to the combat troops and specialized military capabilities the new allies provide, however, the desire to add these to the Alliance's order of battle hardly fully explains the shift in the American position. ${ }^{21}$ To understand why the United States approached the Prague NATO Summit arguing that "we should not calculate how little we can get away with, but how much we can do to advance the cause of freedom," it is necessary to recognize that the Bush Administration's decision to understand the struggle as being one of good against evil, not of West against East or of liberalism against totalitarianism, has important and logically necessary implications for Alliance strategies. ${ }^{22}$

Given this distinctive construction of history, the complete erasure of Yalta's division of Europe into two halves was seen as a necessary step toward rectifying a long-standing wrong. "Yalta did not ratify a natural divide, it divided a living civilization," President Bush proclaimed. "The partition of Europe was not a fact of geography, it was an act of violence." 23 But for the Bush Administration the issue was not simply that Yalta embodied a lie and represented an act of evil and that there was a moral duty to reverse these actions. It was also that NATO had no moral meaning or purpose if the applicant nations were barred from membership and if their brotherhood in the struggle against evil were denied. If "Europe" and the Euro-Atlantic community were to be defined by their embrace of the essential elements of "good" political life - political freedom, economic freedom, and a democratic society - and not by geopolitical concerns, then the applicant nations were (at least arguably) in truth already part of these communities. Continuing to exclude them was perpetuating a lie, an injustice in itself.

Given the weight that the administration's reading of history placed on truth, moral courage and vision, and faith in winning the ongoing struggle against evil, and given the way it read twentieth-century history to underscore the presence of these in American policy toward Europe, a small enlargement of NATO (or no enlargement at all) would logically be both a losing strategy (since it denied truth, lacked moral courage, and abandoned faith) and a violation of America's own history of constancy. Once one understands the distinctive historical and intellectual framework within which the Administration operates, the decision in favor of maximal expansion of NATO appears preordained.

Correcting Europe's boundaries - done most definitively in the American view through changing NATO's boundaries - was seen as an exercise in speaking truth to (admittedly defunct) power. "Our goal is to erase the false lines that have divided Europe for too long," the President announced in

\footnotetext{
${ }^{21}$ The usual list includes Slovenian minesweepers, Czech biological/chemical response units, Polish special forces, Hungarian engineers and military police, Bulgarian decontamination units, Lithuanian doctors, and Estonian canine units.

${ }^{22}$ George W. Bush, "Remarks," Warsaw University, 2.

${ }^{23} \mathrm{Ibid}, 1$.
} 
Warsaw. "The future of every European nation must be determined by the progress of internal reform, not the interests of outside powers. Every European nation that struggles toward democracy and free markets and a strong civic culture must be welcomed into Europe's home."24

Enlarging NATO was thus first and foremost a means of consolidating liberty, to make sure that the victory of the Cold War was in fact irreversible and would not be subverted by evil wearing a new face. Assistant Secretary of State A. Elizabeth Jones made this argument forcefully: "As the President makes clear, U.S. foreign policies must start from our core belief in freedom and democracy 'and look for ways to expand liberty.' This is the underlying logic of NATO's enlargement, to integrate the countries to the east of NATO, [and] former members of the Soviet Union, into the community of shared Western values, and into the Western institutions - of which NATO is the most important that define and defend those values." ${ }^{25}$

Conceptualizing the struggle as one between good and evil also meant a redefinition of who was a useful ally. The Administration's intellectual construction of the situation had two consequences.

First, although the applicant countries might not, on balance, be militarily useful contributors in wars against the old faces of evil - that is, they might not be net assets in a conventional interstate war that might threaten the sovereign territory of current NATO members - against the new faces of evil they might in fact be of great help. If, as the Administration argued, the evil against which NATO warred must be understood in terms of tyrants (such as Milosevic in the Balkans) and terrorists, then these applicant states might possess critical military resources, either in terms of intelligence capabilities or in terms of bases and air space. Thus, after reviewing the contributions of the applicant states to the war on terror, Under-Secretary of State Grossman bluntly summarized the Administration's conclusion: "Bringing in new members will extend the area of security and stability in Europe and bring new allies into our struggle against terrorism. ... If we are to meet new threats to our security, we need to build the broadest and strongest coalition possible of countries that share our values and are able to act effectively with us."26

More important, however, if NATO's struggle were correctly understood as a moral struggle against evil, as the Administration's reading of history suggested, in which victory ultimately went to the side with greater moral courage, faith, and access to transcendent truth, then the contribution of the new allies might be even more substantial. By virtue of their own struggles, they would bring to the Alliance an enormous new reservoir of moral strength.

\footnotetext{
${ }^{24}$ George W. Bush, "Remarks," Warsaw University, 2.

${ }^{25}$ A. Elizabeth Jones, "The Road to NATO's Prague Summit: New Capabilities, New Members, New Relationships," Speech to the World Affairs Council of Northern California, San Francisco, 21 October 2002, 2.

${ }^{26}$ Marc Grossman, "NATO Enlargement," 5.
} 
The notion that the enemy is evil itself thus not only suggested the brotherhood existing between the more longstanding members of the Alliance and former members of the Warsaw Pact, but also suggested the unique qualifications of Eastern European nations for membership. Speaking to a Romanian audience, the President mused, "Your country also brings moral clarity to our NATO Alliance. You value freedom because you have lived without it. You know the difference between good and evil because you have seen evil's face. The people of Romania understand that aggressive dictators cannot be appeased or ignored; they must always be opposed." 27

This influx of fresh moral strength is necessary because there is a danger that the forces of good will become complacent in confronting evil - "it's the normal reaction for people to just kind of settle back and hope that something doesn't exist." ${ }^{28}$ By this line of thinking, the vivid memory of evil possessed by the new allies represented a valuable antidote to this complacency.

This, from an American perspective, meant that the new members of the Alliance would be willing to join in the necessary struggle to destroy evil where it lurked and in the task to spread freedom across the globe. Where the "old" Europe hesitated, the "new" Europe would be courageous and bold. As the President explained, in acknowledging and thanking the U.S. Senate for its unanimous vote to admit new members into NATO, "in the battle of Afghanistan, nations from Central and Eastern Europe supplied soldiers and special forces and peacekeepers to help defeat the Taliban, to help destroy the terrorists and to bring freedom to the Afghan people. In the battle of Iraq, Central and Eastern European countries have stood with America and our coalition to end a grave threat to peace, and to rid Iraq of a brutal ... regime. The peoples of Bulgaria, Estonia, Latvia, Lithuania, Romania, Slovakia, and Slovenia have a fresh memory of tyranny. And they know the consequences of complacency in the face of danger." 29

Thus, specifically in response to the question of what NATO's new members would contribute to the Alliance, given the modest size of their military capabilities, the President bluntly argued: "I do believe they can contribute something really important, and that is they can contribute their love for freedom. These are countries which have lived in totalitarian states. ... And now they've seen freedom and they love freedom ... and that's going to ... add some vigor to the relationship in NATO that's healthy and wholesome." 30

\footnotetext{
${ }^{27}$ George W. Bush, "President Bush Welcomes Romania to NATO,” Bucharest, 1.

${ }^{28}$ Interview of the President by Radio Free Europe/Radio Liberty, 18 November 2002, 2.

${ }^{29}$ George W. Bush, "Remarks by the President with Central European Foreign Ministers," Washington, D.C., 2.

${ }^{30}$ Interview of the President by Radio Free Europe/Radio Liberty, 1.
} 


\section{The Russian Partnership, and the Completion of the European Project}

The first new element in the transformation of NATO thus had to be the admission of new members. Even with this enlargement, however, victory in the great battle for Europe remains incomplete. NATO still remains short of its goal of creating a single Europe, united and free, from the Atlantic to the Urals. The EuroAtlantic project is still unfinished. Another new element in NATO strategy is thus required. This second factor in NATO's transformation, necessary to ensure freedom across Europe, involves the redefinition of how NATO deals with Europe outside its borders. During the Cold War, NATO's boundary was seen as a wall.

Given the Bush Administration's understanding of the current struggle and of history, the completion of the European project demands that NATO use its power and influence to effect a positive transformation in the realm beyond its frontiers. The European project requires a consolidation of liberty in Russia and Russia's integration into Europe as a friend and, hopefully, a partner in the work of peace-building. It requires an end to tyranny in the odd corners of Europe (the Balkans and Belarus) that made a wrong turn in the post-Cold War years - that is, places where evil returned wearing another face. It requires making sure that the Ukraine does not make a wrong turn and that it, too, becomes a friend and partner. And it requires seeing to it that freedom is established in the Eurasian borderlands of the Caucasus and Central Asia. For the most part, the completion of the European project thus involves politico-economic-cultural engagement with NATO's European neighbors. In the former Yugoslavia, however, it has called for military intervention.

Obviously, the most critical element in this transformation and the completion of the European project is the first: a new Russian relationship. "We want Russia to be a partner and an ally - a partner in peace, a partner in democracy, a country that embraces freedom, a country that enhances the security of Europe," President Bush declared in Warsaw. "The definition of the relationship will evolve over time but, first and foremost, it's got to start with the simple word, "friend." "31

This new relationship requires changes on both sides. For the NATO Allies, it requires, as National Security Advisor Rice has argued, recognition "that this is a new day for Europe; that the Cold War is over; that one of the most important aspects of the new Europe is a welcoming and open invitation to Russia to take a rightful place in Europe; that Russia has some important choices to make about its commitment to democratic principles and institutions, about its willingness and ability to live at peace with its neighbors, about its commitment to economic reform; but that the President's vision of Europe is one in which Russia belongs, and fully belongs." 32

\footnotetext{
${ }^{31}$ George W. Bush, "Press Conference of President Bush and President of the Republic of Poland, Alexander Kwasniewski,” Presidential Palace, Warsaw, 15 June 2001, 3.

${ }^{32}$ Condoleezza Rice, "Press Briefing," Warsaw, 3.
} 
While the American vision does not seem to extend so far as to include the possibility of Russia joining NATO, this understanding of a growing partnership between NATO and Russia opens the door to - and indeed demands an unconstrained and ever-expanding agenda for cooperation. "We have done more than just settle old business. We are now entering new territory," Stephen Hadley stated. "Our purpose is to build common security with Russia. Our means are the common projects we have agreed upon, such as developing a joint threat assessment and co-operation on civil emergencies. But we can and should do more. As we tend to this new relationship we must think ambitiously and creatively, asking fundamental questions. For example, should NATO and Russia develop military capabilities to work together to face terrorist threats?" 33

The obstacle blocking such cooperation is not material but mental. It is memory itself that poses the challenge. As Hadley put it, "It has been over a decade since NATO and Russia viewed each other through concertina wire with hostility. Now we must overcome the habits of mind that linger over a divide of different perspectives and different histories." ${ }^{34}$

Beyond Russia, and beyond the uncertainty of developments in the Ukraine, lie the Caucasus and Central Asia. The intellectual challenge in this case is to recognize that these regions now lie within the ambit of NATO's concerns. As Nicholas Burns stated, the new faces of evil reduce the importance of geographic distance: "We must reach eastward to create new political and military ties with the states of Central Asia and the Caucasus. ... As NATO seeks in the future to respond to the threat of terrorism and to instability in the arc of countries ranging from North Africa to the Middle East to South Asia, we need the active support of Armenia, Georgia and Azerbaijan, of Kazakhstan, Uzbekistan, Turkmenistan, Tajikistan, and Kyrgyzstan to protect us and them from the many dangers we all now confront." 35

\section{The Global Mission}

In the Bush Administration's perspective, a transformed NATO will not only complete the European project through enlargement and its engagement with the "other" Europe, but it will also necessarily look beyond Europe, and even beyond Europe's near frontiers. It will adopt a global perspective. Two entirely distinct justifications for this new global perspective have been offered.

At times, this new global mission for NATO is explained in terms of a moral duty. Because the values of NATO are universal rather than civilizational, they are the birthright not simply of Europeans and North Americans but of all humanity. The duty that mankind has toward his fellows in this case has

\footnotetext{
${ }^{33}$ Stephen Hadley, "Challenges and Change for NATO," 3.

${ }^{34}$ Ibid.

${ }^{35}$ Nicholas Burns, "Launching NATO's Transformation at Prague," 3.
} 
global, not merely continental, reach. As the President put it in his Warsaw speech, "Those who have benefited most from the commitment to freedom and openness have an obligation to help others that are seeking their way along that path. This is why our trans-Atlantic community must have priorities beyond the consolidation of European peace." 36 As the President explained to his Polish audience, the same moral imperative that drove the United States to help Western Europe in the 1940s and 1950s, and that drove the United States and Western Europe to embrace Poland in the 1990s, now impelled the United States, Western Europe, and Poland together to come to the assistance of other freedom-loving peoples. "Now, we and others can only go forward together. The question no longer is what others can do for Poland, but what America and Poland can do for the rest of the world." 37

At other times, however, the necessity for NATO to conceive of its mission in global terms is explained in terms of the new global, rather than regional, nature of the threat posed to the free Atlantic community. In other words, as Stephen Hadley explained, "NATO's core mission has not changed. What has changed is the source of the threats to our countries." 38 The embodiment of evil that now endangers free peoples is terrorists and tyrants - "these threats are likely to come less from massing great armies than from small shadowy bands of terrorists. Less from strong states than from weak or failed states, including those led by aggressive dictators," 39 and they are likely to come "less from inside Europe than from exotic locales beyond Europe." 40

As far as the United States is concerned, according to Deputy National Security Adviser Hadley, this understanding of the changed threats confronting NATO that were acknowledged by the Alliance in 2001 "effectively ended the in-area/out-of-area debate that had burned up so much of our time and energies throughout the 1990s. A historical line has been crossed. NATO will go to the Article V threats wherever they are."41

\section{New Capabilities}

The third new item on the Administration's transformative agenda for NATO grows both from the second enunciated element (the new relationship with Europe outside of NATO's borders) and from the new global mission imagined for NATO. Both of these imply a necessary transformation in the Alliance's capabilities. "In devising a new Strategic Concept in 1999, NATO defined these new threats explicitly, noting that 'new risks to Euro-Atlantic peace and stabil-

\footnotetext{
${ }^{36}$ George W. Bush, "Remarks," Warsaw University, 3.

${ }^{37}$ Ibid., 4.

${ }^{38}$ Stephen Hadley, "Challenges and Change for NATO," 2.

${ }^{39}$ Ibid.

${ }^{40}$ Ibid.

${ }^{41}$ Ibid.
} 
ity were becoming clearer - oppression, ethnic conflict, the proliferation of weapons of mass destruction, and the global spread of weapons technology and terrorism," Marc Grossman stated. "In order first to deter and then to defend ourselves against these new threats, NATO needs to be able to deploy at short notice flexible and well-armed forces capable of conducting sustained operations anywhere in the world." 42

It is not simply the new interventionist or expeditionary character of NATO forces and the new - that is to say, global - geographic domain in which they will have to operate that poses a challenge. It is also the sheer unpredictability of the circumstances under which they will be needed. For all the difficulties posed by the Soviet Communist face of evil, at least it was predictable in a way that tyranny and terrorism are not. The lesson of recent history drawn by American leaders is that NATO will need to develop greater military and political flexibility. "We need to think hard about the lessons of the Afghanistan campaign, and what we might need in the future. In addition to new capabilities we need new NATO structures that will allow us to package capabilities to fit new sorts of missions." 43

What goes unsaid, of course, is that the sort of transformation of capabilities that is being promoted by the United States also demands a fundamental political transformation, one that presumably deepens and makes more fundamental the Atlantic relationship, or at least the relationship between European members of the Alliance. Acquiring the new capabilities demanded by the United States will require a pooling of resources among NATO members, since individual member-states will, typically, be unable to afford all of the critical capabilities identified (e.g., "defenses against nuclear, chemical and biological weapons, both protection and detection"; "better counter-terrorism capabilities"; "ground surveillance"; "strategic air lift"; and "precision strike capabilities, meaning more unmanned aerial vehicles, [and] more precision-guided munitions"44). As most of the NATO members become increasingly specialized providers of niche capabilities, they will inevitably become more interdependent. Indeed, as U.S. policymakers have suggested, affording these new capabilities is likely to demand that members abandon what has been both a symbol and a pillar of the modern nation-state: mass conscript armies. ${ }^{45}$

Where the obstacle faced by the United States in advancing the other two new elements of NATO transformation has been (from the American perspective) a failure of imagination, the obstacle in the case of the third element has been a failure of will and resolve. As American spokesmen repeatedly point out, what needs to be done has been identified. NATO members, however, have been reluctant to pay the necessary price to carry through on their verbal commitments.

${ }^{42}$ Marc Grossman, "NATO Enlargement," 4. Emphasis added.

${ }^{43}$ Stephen Hadley, "Challenges and Change for NATO," 2.

${ }^{44}$ Ibid.

${ }^{45}$ Nicholas Burns, "Launching NATO's Transformation at Prague," 2. 


\section{Conclusions}

A careful reading of Bush Administration statements thus suggests a fascinating, intellectually coherent - if not necessarily intellectually convincing account of the past, present, and future of the Atlantic partnership. Starting with a framework that emphasizes the struggle of good against evil, this administration has constructed a history that emphasizes American constancy - American faith in a Europe whole, free, and at peace, American partnership in the Atlantic Alliance, and American friendship with all the nations of Europe - and the changing face, though not fundamental character, of the evil confronted.

This conceptualization of the world and this account of Atlantic history logically imply both the continued centrality of the NATO Alliance and the need to transform that Alliance. The three new requirements articulated by the Bush Administration - new members for NATO, new relationships with nonNATO Europe, and new capabilities - as well as the Administration's insistence on globalizing NATO's perspective follow directly from this understanding of reality.

Ironically, it is the very coherence and internal consistency of the Bush Administration's vision - a vision based on a belief in a universal, enduring struggle of good against evil, in which NATO has always played and will always play a central role - that is likely to prove problematic for the Alliance. The extraordinary coherence and the self-justifying internal consistency of the Administration's understanding of the world and of history is likely to convince it that this understanding is both accurate and universally shared. Allies who start with a different conception of the nature of world politics, or of good and evil, or of the history of the Atlantic relationship, are likely to find themselves challenging not only particular American policies but the entire American cosmology. Because the injunction, "No more Munichs, no more Yaltas," is likely to have very different meanings for different audiences, the next stopping point on the road that has led from Warsaw to Prague may be more problematic than the Bush Administration assumes. 


\section{Bibliography}

A. Jones, Elizabeth. The Road to NATO's Prague Summit: New Capabilities, New Members, New Relationships In Speech to the World Affairs Council of Northern California. San Francisco, 2002.

Bush, George W. President Bush Meets with Central European Foreign Ministers: Remarks by the President with Central European Foreign Ministers. Washington, D.C.: the White House, 2003.

Bush, George W. President Bush Welcomes Romania to NATO: Remarks by the President to the Citizens of Romania. Bucharest, Romania, 2002.

Bush, George W. Press Conference of President Bush and President of the Republic of Poland, Alexander Kwasniewski. Warsaw: Presidential Palace, 2001.

Remarks by the President at Opening of NATO Meeting. Brussels, Belgium: NATO Headquarters, 2001.

Bush, George W. Remarks, Vilnius 2002 In 23 Novem 2002., 2002.

Bush, George W. Remarks, Warsaw University 2001., 2001.

Grossman, Marc. NATO Enlargement: Remarks to the Chicago Council on Foreign Relations. Chicago, 2002.

Hadley, Stephen. Challenges and Change for NATO. NATO, 2002.

Powell, Colin L. An Enlarged NATO: Mending Fences and Moving Forward on Iraq In Testimony before the Senate Foreign Relations Committee. Washington, D.C., 2003.

R. Burns, Nicholas. Launching NATO's Transformation at Prague In Manfred Woerner Memorial Lecture. Berlin, Germany: Konrad Adenauer Stiftung, 2002.

Rice, Condoleezza. Press Briefing by National Security Advisor Condoleezza Rice. Warsaw, Poland: Warsaw Marriott Hotel, 2002.

The National Security Strategy of the United States of America., 2002.

Porta, Donatella Della. Introduction: On Individual Motivations in Underground Political Organizations. Greenwich, CT: JAI Press, 1992.

Tarrow, Sidney. "Political Protest and Social Change: Analyzing Politics." American Political Science Review 90, no. 4 (1996).

Tarrow, Sidney. Power in Movement: Social Movements and Contentious Politics. New York: Cambridge University Press, 1998.

Tilly, Charles. "From Interactions to Outcomes in Social Movements." In How Social Movements Matter. Minneapolis: University of Minnesota Press, 1999. 
Waldmann, Peter. Ethnic and Sociorevolutionary Terrorism: A Comparison of Structures., 1992.

Zald, Mayer N.. "Resource Mobilization and Social Movements: A Partial Theory." American Journal of Sociology 82, no. 6 (1977): 1212-41 .

Zeidan, David. "Radical Islam in Egypt: A Comparison of Two Groups." In Revolutionaries and Reformers: Contemporary Islamist Movements in the Middle East, 11-22. Albany: State University of New York Press, 2003. 